\title{
Forage characters of different Paspalum species in Rio Grande do Sul: a meta-analysis
}

\author{
Larissa Arnhold Graminho ${ }^{1^{*}}$ Miguel Dall'Agnol ${ }^{1}$ Luciana Pötter $^{2}$ Rodrigo Ramos Lopes $^{1}$ \\ Carine Simioni ${ }^{1}$ Roberto Luís Weiler ${ }^{1}$
}

${ }^{1}$ Departamento de Plantas Forrageiras e Agrometeorologia, Universidade Federal do Rio Grande do Sul (UFRGS), 90040-060, Porto Alegre, RS, Brasil. E-mail:laraarnhold@hotmail.com. ${ }^{*}$ Corresponding author.

${ }^{2}$ Departamento de Zootecnia, Centro de Ciências Rurais (CCR), Universidade Federal de Santa Maria (UFSM), Santa Maria, RS, Brasil.

\begin{abstract}
The objective of this study was to evaluate, through meta-analysis, the forage characteristics of various species of the genus Paspalum and to use them to select the best ecotypes that can be used in artificial hybridization as parents and hybrids for pasture production and natural pasture recovery systems. Data were obtained from studies conducted by the Department of Forage Plants and Agrometeorology of the Universidade Federal do Rio Grande do Sul. Database comprised tests conducted with ecotypes and/or hybrids of Paspalum spp. in plots for evaluating total dry mass production, leaf dry mass production, and stem dry mass production by means of cuts. Total dry mass production, which included leaves and stems, differed between the ecotypes and hybrids. Hybrid H12 was the most divergent of all evaluated accessions. The greatest genetic divergence occurred due to dry mass production. Hybrids showed high total dry mass production, comprised mainly of leaves. Hybrid H12 and the accession of Paspalum lepton $28 \mathrm{E}$ were identified as the most dissimilar based on the generalized Mahalanobis distance using Tocher's method. Total dry mass production is the characteristic that most contributed to the detection of genetic variability. Key words: apomixis, hybridization, plant breeding, natural pasture, variability.
\end{abstract}

Caracteres forrageiros de diferentes espécies do gênero Paspalum no Rio Grande do Sul: uma meta-análise

RESUMO: O objetivo deste trabalho foi avaliar, por meio de meta-análise, a variabilidade dos caracteres forrageiros de espécies do gênero Paspalum e utilizá-los para selecionar os melhores ecótipos para serem utilizados em hibridações artificiais como genitores e híbridos para serem empregados em sistemas de produção a pasto e recuperação de pastagens naturais. Os dados foram obtidos a partir ensaios, do Departamento de Plantas Forrageiras e Agrometeorologia da Universidade Federal do Rio Grande do Sul. A base de dados foi composta por ensaios conduzidos com ecótipos elou híbridos do gênero Paspalum, em parcelas, avaliando por meio de cortes a produção de massa seca total, de folhas e colmos. Houve diferença entre ecótipos/hibridos para produção de matéria seca total, de folhas e colmos. O hibrido H12 foi o mais divergente dos acessos avaliados. A maior divergência genética ocorreu devido à produção de massa seca. Os híbridos apresentam elevada produção de massa seca total, sendo esta composta principalmente por folhas. O método de Tocher utilizando a distância generalizada de Mahalanobis identifica o hibrido H12 e o acesso de Paspalum lepton 28 E como os mais dissimilares. A produção de massa seca total é o caractere que mais contribui para a detecção da variabilidade genética.

Palavras-chave: apomixia, hibridação, melhoramento genético, pastagem natural, variabilidade.

\section{INTRODUCTION}

Grasses of the genus Paspalum are the most important forage plants used in pastures in South America (NOVO et al., 2015). In particular, Rio Grande do Sul has soil and climate conditions that enable species of the genus Paspalum to adapt well ecologically, resulting in increased forage production.

Several studies have highlighted that species of the genus Paspalum, being native, have advantages over exotic plants and high inter- and intraspecific variabilities in forage characteristics (REIS et al., 2010; PEREIRA et al., 2011; PEREIRA et al., 2012). As a result, there is great potential for exploiting these species in genetic improvement programs for using them as forage plants (REIS et al., 2010). Identifying the characteristics of species favorable to productive exploitation; will therefore, enable the selection of superior materials as cultivars. 
Apomixis is the predominant reproduction method in polyploid species of the genus Paspalum. However, it hinders genetic recombination as well impairs cultivar protection because of legal regulations (PEREIRA et al., 2012). However, hybridization, when one of the parents exhibits sexual reproduction, can result in variability and allows the selection of progenies with immediate fixation of characteristics of interest due to apoximis (ACUÑA et al., 2009).

Meta-analyses combined the results of several studies to create a reproducible and quantifiable summary of data, thereby improving the statistical power in studies on the effects of treatments and improving precision in the estimation and size of the effect (LOVATTO et al., 2007). An evaluation of variability in the expression of forage characteristics of interest and of the genetic diversity of ecotypes and hybrids of different species of the genus Paspalum by means of a meta-analysis enables the comparison of data from different trials, thus increasing the number of ecotypes, hybrids, and repetitions evaluated. It also provided information for the selection of superior plants as well as the formation of new elite recombinants. Therefore, the objective of this study was to evaluate, through a meta-analysis, the forage characteristics of species of the genus Paspalum and to use them to select the best ecotypes for use in artificial hybridization as parents and hybrids in pasture production and natural pasture recovery systems.

\section{MATERIALS AND METHODS}

Data were obtained from studies conducted between 2002 and 2014 by the Department of Forage Plants and Agrometeorology of the Universidade Federal do Rio Grande do Sul, in which the forage characteristics of ecotypes and hybrids of the genus Paspalum were evaluated.

As criteria for inclusion in the database, the studies had to have been conducted in Rio Grande do Sul with ecotypes and/or hybrids of the genus Paspalum in plots, free from animal grazing for two agricultural years and total dry mass production (TDMP), leaf dry mass production (LDMP), and stem dry mass production (SDMP) had to be determined by means of cuts and expressed as $\mathrm{kg}$ of DM per hectare per year ( $\mathrm{kg} \mathrm{DM} \mathrm{ha-1}$ year $\left.^{-1}\right)$. TDMP, LDMP, and SDMP were calculated by the sum of the cuts performed in each agricultural year. Different years and locations were treated as repetitions.

Because only a few trials reported the leaf:stem ratio (LSR) and harvest index (HI), we calculated these variables using the following formulae: LSR = LDMP/SDMP(PEREIRA et al., 2012; PEREIRA et al., 2015; MOTTA et al., 2017) and HI = LDMP/ TDMP (PEREIRA et al., 2012), respectively.

Data from six studies were used in the database: SANTOS (2005), STEINER (2005), SAWASATO (2007), TOWNSEND (2008), PEREIRA et al. (2012), and MOTTA et al. (2017) The studies produced 135 observations on the following species: Paspalum notatum, ecotypes André da Rocha and Bagual, and the commercial cultivar 'Pensacola'; $P$. guenoarum, ecotypes Azulão, Baio, and the cultivar 'Rojas'; P. urvillei: accessions collected in Rio Grande do Sul, in the municipalities of André da Rocha, Eldorado do Sul, and Bagé; P. lepton: accessions collected in Rio Grande do Sul, in the municipalities of Alegrete (26A and 26D) and Rosário do Sul (28B, 28C, and 28E); P. denticulatum and $P$. pauciciliatum. Two different species belonging to other genera, Panicum maximum Jacq. cv. 'Aruana' and the species popularly known as giant missionary grass (Axonopus catharinensis Valls), were used as controls.

Genotypes and artificial hybrids productivity data were also evaluated at the premises of the Instituto de Botánica del Nordeste (IBONE), which is based at the School of Agrarian Sciences in the province of Corrientes in Argentina. The P. guenoarum ecotype 'Rojas' was used as the male parent, and the $P$. plicatulum sexual genotype $4 \mathrm{c}-4 \mathrm{x}$ was used as the female parent. The chromosomal set of the sexual genotype was duplicated with colchicine (SARTOR et al., 2009) to enable cross-breeding between the different species and promote the production of fertile offspring. Hybrids evaluated (H12, H13, H20, and H22) were selected for their higher TDMP, as described by PEREIRA et al. (2015) and MOTTA et al. (2017).

After the normality test, the data were analyzed using a mixed model that considered ecotypes/hybrids as fixed effects and experiments and repetitions as random effects. Nine variance and covariance matrix models were tested as follows: variance component (VC), compound symmetry (CS), unstructured (UN), first-order autoregression [AR(1)], heterogeneous first-order autoregression [ARH(1)], heterogeneous compound symmetry (CSH), firstorder autoregression with moving averages [ARMA $(1,1)]$, and first-order ante-dependence [ANTE(1)]. Selection of the best matrix model was based on the Bayesian Information Criterion. When differences were detected, the means were compared using the LSMEANS procedure with $10 \%$ probability. These procedures were performed using the SAS statistical package, version 9.2 (SAS, 2002). 
Multivariate analysis was performed with the GENES Program (CRUZ, 2007) using the generalized distance of Mahalanobis $\left(\mathrm{D}^{2}\right)$ to estimate the existing genetic dissimilarity between the ecotypes and hybrids. Tocher's method was used as the technique for grouping the evaluated materials. Finally, to define the total variability observed, the magnitude of the relative contribution of the variables $(\mathrm{Sj})$ was determined by Singh's model (SINGH, 1981).

\section{RESULTS AND DISCUSSION}

There was a difference in TDMP between the ecotypes/hybrids $(\mathrm{P}=0.0645$; Table 1$)$. The 'Aruana' (Panicum maximum) and 'Rojas' ( $P$. guenoarum) cultivars had higher TDMP, with an average of $20467 \mathrm{~kg}$ of DM ha ${ }^{-1} \mathrm{year}^{-1}$, which was $51 \%$ greater than that observed in ecotypes with lower TDMP, which averaged $9997 \mathrm{~kg}$ of DM ha $^{-1}$ year $^{-1}$ (Table 1). For P. guenoarum ecotypes Azulão and Baio and the P. lepton accessions, TDMP was intermediate at $12463 \mathrm{~kg}$ of $\mathrm{DM} \mathrm{ha} \mathrm{ha}^{-1} \mathrm{yer}^{-1}$ (Table 1). The evaluated hybrids had an average TDMP of $19255 \mathrm{~kg}$ of DM ha ${ }^{-1} \mathrm{year}^{-1}$, similar to the production observed in superior and intermediate materials (Table 1). These results demonstrate the high potential of the materials evaluated under the soil and climatic conditions of Rio Grande do Sul. Although some of these materials were commercial cultivars, the native genotypes never underwent any genetic improvement but had high forage yields.

Even though hybridization was performed with parents of different species, TDMP of the hybrids and of their male parent $P$. guenoarum Rojas was similar, with no significant gains in productivity being confirmed. This may indicate genetic proximity between the parents because according to PATERNIANI \& CAMPOS (2005), hybrid vigor occurs when the genetic distance between parents is high.

TDMP of 'Pensacola' was lower than the averages observed in the hybrids (97\%), $P$. guenoarum ecotypes (60\%), P. lepton accessions

Table 1 - Total dry mass production (TDMP), leaf dry mass production (LDMP), and stern dry mass production (SDMP) in kg of DM per hectare per year of ecotypes/hybrids of the genus Paspalum, Panicum maximum Jacq. cv. 'Aruana', and Axonopus catharinensis evaluated in Rio Grande do Sul (2002-2014).

\begin{tabular}{|c|c|c|c|}
\hline Ecotype & TDMP & LDMP & SDMP \\
\hline Panicum maximum Aruana & $20364 a$ & $12459 b$ & $6887 \mathrm{a}$ \\
\hline Axonopus catharinensis & $10442 \mathrm{c}$ & $6627 \mathrm{~cd}$ & $2624 c$ \\
\hline P. guenoarum Azulão & $12651 b$ & $8339 c$ & $3202 b$ \\
\hline P. guenoarum Baio & $12956 b$ & $8211 \mathrm{c}$ & $3472 b$ \\
\hline P. guenoarum Rojas & $20569 a$ & $15023 a$ & $4885 \mathrm{ab}$ \\
\hline P. notatum André da Rocha & $10080 \mathrm{c}$ & $6392 \mathrm{~cd}$ & $3111 b$ \\
\hline P. notatum Bagual & $10716 \mathrm{c}$ & $6845 \mathrm{~cd}$ & $3103 b$ \\
\hline P. notatum Pensacola & $9764 c$ & $6502 \mathrm{~cd}$ & $1819 \mathrm{c}$ \\
\hline P. lepton 26A & $12407 b$ & $8154 \mathrm{c}$ & $2126 c$ \\
\hline P. lepton 26D & $12279 b$ & $8404 c$ & $1933 c$ \\
\hline P. lepton $28 \mathrm{~B}$ & $13139 b$ & $8182 \mathrm{c}$ & $2820 \mathrm{~b}$ \\
\hline P. lepton $28 \mathrm{C}$ & $12185 b$ & $8284 c$ & $2062 c$ \\
\hline P. lepton $28 \mathrm{E}$ & $11622 b$ & $7361 \mathrm{c}$ & $2153 c$ \\
\hline P. urvillei (André da Rocha) & $10430 \mathrm{c}$ & $7169 \mathrm{~cd}$ & $2620 c$ \\
\hline P. urvillei (Bagé) & $9806 c$ & $7323 \mathrm{~cd}$ & $2228 c$ \\
\hline P. urvillei (Eldorado do Sul) & $9746 c$ & $7185 \mathrm{~cd}$ & $2022 \mathrm{c}$ \\
\hline P. denticulatum & $8010 \mathrm{c}$ & $4868 d$ & $1154 \mathrm{c}$ \\
\hline P.pauciciliatum & $10977 \mathrm{c}$ & $5626 \mathrm{~d}$ & $3261 b$ \\
\hline \multirow{2}{*}{\multicolumn{4}{|c|}{ H12 $19424 \mathrm{ab} \quad 15135 \mathrm{a}$}} \\
\hline & & & \\
\hline H13 & $19700 \mathrm{ab}$ & $14751 \mathrm{ab}$ & $3595 b$ \\
\hline $\mathrm{H} 20$ & $19115 \mathrm{ab}$ & $12821 \mathrm{ab}$ & $3042 b$ \\
\hline $\mathrm{H} 22$ & $18782 \mathrm{ab}$ & 14789ab & $3107 b$ \\
\hline $\mathrm{P}$ & 0.0645 & 0.0307 & 0.0864 \\
\hline
\end{tabular}

Averages followed by the same letters in the columns did not differ according to the LSMEANS test at $10 \%$ probability. 
(27\%), P. notatum ecotypes (6.5\%), and P. urvillei accessions $(2.3 \%)$. This comparison is important because the 'Pensacola' cultivar and $P$. atratum cv. 'Pojuca' are the only cultivars with seeds available in the Brazilian market.

Differences in LDMP were observed between the ecotypes/hybrids ( $\mathrm{P}=0.0307$; Table 1$)$. LDMP was higher in P. guenoarum cv. 'Rojas' and in hybrid H12, with an average of $15079 \mathrm{~kg}$ of DM ha $^{-1}$ year $^{-1}$ (Table 1). The other hybrids H13, H20, and H22 had LDMP similar to that of the two highproductivity materials and cultivar 'Aruana', which had intermediate leaf production (Table 1). The $P$. denticulatum and P. pauciciliatum ecotypes yielded lower LDMP, which was expected, as they also had lower TDMP (Table 1).

Leaf production is a very important characteristic because leaves are responsible for photosynthesis (RODRIGUES et al., 2008); they are the preferred structures consumed by animals and have the highest nutritional quality (BRATTI et al., 2009). According to PEREIRA et al. (2011), it is essential that selection for increased leaf production and reduced stem production be targeted in forage plant improvement, as showed by hybrid H12, which had LDMP of $132 ; 7.1 \%$, This value was higher than that of the commercial cultivar 'Pensacola' as well as the average leaf production of the hybrids.

Differences in SDMP were observed between the ecotypes/hybrids ( $\mathrm{P}=0.0463$; Table 1). SDMP was higher for the cultivar 'Aruana', with $6887 \mathrm{~kg}$ of DM ha ${ }^{-1}$ year $^{-1}$, which was $30 \%$ higher than that observed for P. guenoarum 'Rojas'. The cv. 'Rojas' was the second highest producer of stems and was also similar to the $P$. guenoarum ecotypes Azulão and Baio, P. notatum André da Rocha and Bagual, and P. lepton accession 28B (Table 1). We reported that $33 \%, 24 \%$, and $17 \%$ of TDMP of 'Aruana', $P$. guenoarum, and the hybrids, respectively, were composed of stems, which indicated that the hybrids brought benefits not only by increasing TDMP but also by improving the structural characteristics of the plants, resulting in a lower proportion of components that are less important for livestock grazing.

There were no differences between the ecotypes/hybrids in either the LSR $(\mathrm{P}=0.3580)$ or HI $(\mathrm{P}=0.7108)$, with averages of 4.1 and 0.50 , respectively, and these data were used to estimate the Mahalanobis distance, Tocher clustering, and relative contribution to variability.

The measurements of genetic dissimilarity demonstrated a high magnitude (0.11-107.2), which indicated a broad range of genetic variability among the ecotypes/hybrids (Table 2). Combinations of hybrids $\mathrm{H} 12, \mathrm{H} 20$, and $\mathrm{H} 13$ with $P$. lepton accession 28 E and of hybrid H12 with P. lepton accession 26A had the highest divergence, with distances of 107.2, 101.2, 95.8, and 96.1, respectively.

In general, genotypes which present greater distance also have a greater genetic distance among them. Thus, the estimate of genetic dissimilarity becomes very important because when combined with knowledge about the performance of parents, it provides an alternative to cross-breeding by indicating genetic contributions with high combining capacities (VIEIRA et al., 2005)

In relation to the maximum distance obtained between all possible combinations of the ecotypes evaluated, we observed that most genotypes exhibited the maximum distance when combined with hybrid $\mathrm{H} 12$, which indicated that it was the most divergent of the materials evaluated. Thus, hybrid H12 can be used as a parent in future hybridization, because according to PEREIRA et al. (2015), genotypes that are genetically distant offer possibilities for new crosses targeting the formation of elite recombinants.

The smallest distances were observed between the $P$. urvillei accessions from Bagé and Eldorado do Sul $\left(\mathrm{D}^{2}=0.11\right)$, between the $P$. guenoarum ecotypes Azulão and Baio $\left(\mathrm{D}^{2}=0.15\right)$, and between the P. lepton accessions 26D and 28C $\left(\mathrm{D}^{2}=0.30\right)$. Smaller distance between the ecotypes $P$. guenoarum Azulão and Baio may be because they are of the same species and that the evaluated agronomic characteristics are similar. Although, cultivar 'Rojas' belongs to the same species, it had greater TDMP, LDMP, and SDMP, which may explain why its values of genetic dissimilarity were close to those of the Azulão and Baio ecotypes. For P. urvillei (Bagé and Eldorado do Sul) and P. lepton (26D and 28C), the smaller distances may have occurred because they are the same ecotypes, although they were harvested in different regions.

Cluster analysis using Tocher's method resulted in the formation of three distinct groups (Table 3). There were 16 ecotypes in Group I, representing $72 \%$ of the materials evaluated, which indicated that crosses among these ecotypes, when viable, could reduce the possibility of obtaining superior genotypes. Groups II and III were composed of 5 and 1 ecotypes/hybrids, representing 23\% and $5 \%$ of the evaluated materials, respectively (Table 3 ).

Formation of groups is important for targeting potential new hybrid combinations because they should be based on the magnitude of their 
Table 2 - Estimates of the Mahalanobis distances $\left(\mathrm{D}^{2}\right)$ based on five variables ${ }^{(1)}$ in the ecotypes and hybrids of Paspalum, Panicum maximum Jacq. cv 'Aruana,' and Axonopus catharinensis evaluated in Rio Grande do Sul (2002-2014).

\begin{tabular}{|c|c|c|c|c|c|}
\hline Ecotype/hybrid & Greatest $\mathrm{D}^{2}$ & Most distant ecotype/hybrid & Smallest $\mathrm{D}^{2}$ & Closest Ecotype/hybrid & Average $\mathrm{D}^{2}$ \\
\hline Panicum maximum Aruana & 71.11 & Pni28E & 13.8 & PgRojas & 40.0 \\
\hline Axonopus catharinensis & 66.90 & H12 & 1.13 & Ppauc & 21.7 \\
\hline P.guenoarum Azulão & 52.43 & H12 & 0.15 & PgBaio & 19.7 \\
\hline P. guenoarum Baio & 52.60 & H12 & 0.15 & $\operatorname{PgAz}$ & 19.4 \\
\hline P. guenoarum Rojas & 87.60 & Pni28E & 2.60 & $\mathrm{H} 13$ & 44.9 \\
\hline P. notatum André da Rocha & 78.70 & H12 & 2.90 & PnBagual & 30.0 \\
\hline P. notatum Bagual & 66.51 & $\mathrm{H} 12$ & 2.90 & PnAR & 24.0 \\
\hline P. notatum Pensacola & 80.42 & $\mathrm{H} 12$ & 3.80 & Pdenticulatum & 26.7 \\
\hline P. lepton $26 \mathrm{~A}$ & 96.10 & $\mathrm{H} 12$ & 0.53 & Pni28C & 31.8 \\
\hline P. lepton 26D & 92.40 & $\mathrm{H} 12$ & 0.30 & Pni28C & 28.6 \\
\hline P. lepton 28B & 95.60 & $\mathrm{H} 12$ & 0.53 & Pni26A & 30.5 \\
\hline P. lepton $28 \mathrm{C}$ & 95.50 & $\mathrm{H} 12$ & 0.30 & Pni26D & 30.6 \\
\hline P. lepton $28 \mathrm{E}$ & 107.21 & $\mathrm{H} 12$ & 0.65 & Pni26A & 32.2 \\
\hline P. urvillei (André da Rocha) & 77.60 & $\mathrm{H} 12$ & 0.30 & PuBagé & 25.8 \\
\hline P. urvillei (Bagé) & 77.14 & $\mathrm{H} 12$ & 0.11 & PuES & 24.9 \\
\hline P. urvillei (Eldorado do Sul) & 75.00 & $\mathrm{H} 12$ & 0.11 & PuBagé & 23.4 \\
\hline P. denticulatum & 76.90 & $\mathrm{H} 12$ & 1.90 & Axocath & 20.3 \\
\hline P. pauciciliatum & 71.32 & H12 & 1.13 & Axocath & 21.5 \\
\hline H12 & 107.20 & Pni28E & 34.8 & H22 & 70.0 \\
\hline H13 & 95.80 & Pni28E & 0.57 & $\mathrm{H} 22$ & 49.8 \\
\hline $\mathrm{H} 20$ & 101.24 & Pni28E & 1.17 & $\mathrm{H} 22$ & 54.0 \\
\hline $\mathrm{H} 22$ & 90.51 & Pni28E & 0.57 & H13 & 46.3 \\
\hline
\end{tabular}

${ }^{(1)}$ Total dry mass production (TDMP); Leaf dry mass production (LDMP); Stem dry mass production (STDM); Leaf: stem ratio (LSR); Harvest index (HI).

dissimilarity and the potential of parents. However, in addition to being dissimilar, parents should combine medium and high variability with regard to the characteristics being improved (ALMEIDA et al., 2011).

Analysis of the relative contribution to total variability showed that $78.8 \%$ of the genetic divergence occurred as a result of TDMP, whereas LSR, LDMP, SDMP, and HI had a contribution of only $21.2 \%$ (Table 4). PEREIRA et al. (2015) analyzed the agronomic ecotypes and hybrids of the genus Paspalum (individual plants) and reported that the relative variability contribution of TDMP to genetic divergence was $46.2 \%$, whereas the other seven evaluated variables accounted for $53.8 \%$ of the variability observed.

The fact that TDMP makes the greatest contribution to variability indicates that it was the

Table 3 - Breakdown of the genetic dissimilarity of ecotypes and hybrids of the genus Paspalum, Panicum maximum Jacq. cv 'Aruana', and Axonopus catharinensis evaluated using Tocher's cluster analysis (Rio Grande do Sul: 2002-2014).

Groups Clustering

P. urvillei (Bagé), P. urvillei (Eldorado do Sul), P. urvillei (André da Rocha), P. lepton 28B, P. pauciciliatum, P. lepton 28C, P. lepton 26D, P. lepton 26A, P. lepton 28E, P. denticulatum, Axonopus catharinensis, P. notatum Pensacola, $P$. guenoarum Baio, P. guenoarum Azulão, P. notatum Bagual, P. notatum André da Rocha 
Table 4 - Relative contribution to the variability of characteristics associated with the forage potential of ecotypes and hybrids of the genus Paspalum, Panicum maximum Jacq. cv. 'Aruana', and Axonopus catharinensis based on the generalized Mahalanobis distance (Rio Grande do Sul: 2002-2014).

\begin{tabular}{lll}
\hline Variable & $\mathrm{Sj}^{(1)}$ & $\mathrm{Sj}(\%)^{(2)}$ \\
\hline Total dry mass production (TDMP) & 6395 & 79 \\
Leaf dry mass production (LDMP) & 637 & 8 \\
Stem dry mass production (SDMP) & 274 & 3 \\
Leaf:stem ratio (LSR) & 648 & 8 \\
Harvest index (HI) & 163 & 2 \\
\hline
\end{tabular}

most effective variable for expressing the variability among genotypes and demonstrated its importance as a component in the selection of genotypes with superior forage characteristics. ALVES et al. (2003) reported the importance of determining the relative contribution of characteristics to reduce the number of evaluations necessary to determine genetic variability, given that only characteristics that effectively contributed to this variability can be measured. Smaller contribution to the genetic variability by botanical separation and structural components, when compared to TDMP, suggested that the measurements could be discontinued, because it required excessive labor and time in return for a relatively small contribution to variability.

\section{CONCLUSION}

The hybrids exhibited high TDMP, composed mostly of leaves, with a smaller proportion of stems than that observed in the ecotypes with similar or higher TDMP. The P. guenoarum genotypes Rojas, Baio, and Azulão stood out in terms of TDMP and could be used in future crosses. Tocher's method using generalized Mahalanobis distance allowed us to identify hybrid H12 and P. lepton accession 28E as the most dissimilar and the P. urvillei accession from Bagé and Eldorado do Sul as the most similar. TDMP is the characteristic that contributes most to the detection of genetic variability.

\section{ACKNOWLEDGEMENTS}

We would like to thank Conselho Nacional de Desenvolvimento Científico e Tecnológico (CNPq), Coordenação de Aperfeiçoamento de Pessoal de Nível Superior (CAPES), and SulPasto for the financial support and human resources.

\section{REFERENCES}

ACUÑA, C.A. et al. Bahiagrass tetraploid germplasm: reproductive and agronomic characterization of segregating progeny. Crop Science, v.49, p.581-588, 2009. Available from: $<$ http://www.crops.org/publications/cs/articles/49/2/581?highli ght $=\&$ search-result=1>. Accessed: Oct. 24, 2016. doi: 10.2135/ cropsci2008.07.0402.

ALMEIDA, R.D. et al. Genetic divergence among soybean cultivars, under irrigated conditions, in south Tocantins State. Revista Ciência Agronômica, v.42, p.108-115, 2011. Available from: <http://www.ccarevista.ufc.br/seer/index.php/ccarevista/ article/view/1143/515>. Accessed: Oct 24, 2016. doi: 10.1590/ S1806-669020110001000100014.

ALVES, R.M. et al. Selection of morpho-agronomic descriptors for cupuaçuzeiro germplasm characterization. Pesquisa Agropecuária Brasileira, v.38, p.807-818, 2003. Available from: $<$ http://www.scielo.br/scielo.php?script=sci_arttext\&pid=S0100204X2003000700004>. Accessed: Oct. 24, 2016. doi: 10.1590/ S0100-204X2003000700004.

BRATTI, L.F.S. et al. Ingestive behavior of goats in ryegrass and black oat pastures in pure or mixture. Ciência Animal Brasileira, v.10, p.397-405, 2009. Available from: $<$ https://www.revistas.ufg. br/vet/article/view/548/4830>. Accessed: Nov. 23, 2016.

CRUZ, C.D. Programa GENES: aplicativo computacional em genética e estatística. Viçosa: UFV, 2007. 442p.

LOVATTO A.P. et al. Meta-analysis in scientific research: a methodological approach. Revista Brasileira de Zootecnia, v.36, p.285-294, 2007. Available from: <http://www.scielo.br/ scielo.php?script=sci_arttext\&pid=S151635982007001000026 $>$. Accessed:Nov.23,2016. doi: 10.1590/S1516-35982007001000026.

MOTTA, E.A.M. et al. Forage value of superior interspecific hybrids of Paspalum. Revista Ciência Agronômica, v.48, n.1, p.191-198, 2017. Available from: <http://www.ccarevista.ufc.br/ seer/index.php/ccarevista/article/view/4643>. Accessed: Nov. 11, 2016. doi: $10.5935 / 1806-6690.20170022$.

NOVO, P.E. et al. Interspecific hybrids between Paspalum plicatulum and P. oteroi: a key tool for forage breeding. Scientia Agricola, v.73, p.356-362, 2015. Available from: <http://www. scielo.br/pdf/sa/v73n4/0103-9016-sa-73-4-0356.pdf >. Accessed: Oct. 24, 2016. doi: 10.159010103-9016-2015-0218.

PATERNIANI, E.; CAMPOS, M.S. Melhoramento do milho. In: BORÉN, A. (Ed.). Melhoramento de espécies cultivadas. 2.ed. Viçosa: UFV, 2005. p.491-533.

PEREIRA, E.A. et al. Agronomic production of a collection of Paspalum lepton Parodi acess. Revista Brasileira de Zootecnia, v.40, p.498-508, 2011. Available from: <http://www.scielo. br/scielo.php?pid $=$ S1516-35982011000300006\& script $=$ sci arttext>. Accessed: Oct. 17, 2016. doi: 10.1590/S151635982011000300006 .

PEREIRA, E.A. et al. Genetic variability of forage traits Paspalum. Pesquisa Agropecuária Brasileira, v.47, p.1533-1540, 2012. Available from: $\quad<$ http://www.scielo.br/scielo.php?script=sci arttext\&pid=S0100-204X2012001000017>. Accessed: Oct 24, 2016. doi: $10.159 / \mathrm{S} 0100-204 \times 2012001000017$. 
PEREIRA, E.A. et al. Agronomic performance and interspecific hybrids selection of the genus Paspalum. Científica, v.43, p.388395, 2015. Available from: <http://cientifica.org.br/index.php/ cientifica/article/view/753/450>. Accessed: Oct. 24, 2016. doi: $10.15361 / 198455292015 \mathrm{v} 43 \mathrm{n} 4.388-385$.

RODRIGUES R.C. et al. Dry matter production, leaf/stem ratio and growth indexes of palisade grass (Brachiaria brizantha cv. 'Xaraés'), cultivated with different rate combinations of nitrogen and potassium. Revista Brasileira de Zootecnia, v.37, p.394-400, 2008. Available from: <http:/www.scielo.br/scielo php?pid=S1516-35982008000300003\&script $=$ sci_arttext $>$. Accessed: Oct. 05, 2016. doi: 10.1590/S1516-35982008000300003.

REIS, C.A.O. et al. Morphological variation in Paspalum lepton Parodi accessions, a promising forage. Scientia Agricola, v.67, p.143-150, 2010. Available from: <http://www.scielo.br/scielo. php script $=$ sci_arttext $\&$ pid $=S 0103-90162010000200003>$. Accessed: Oct, 24 , 2016. doi: 10.1590/S0103-9016201000020003.
SARTOR, M.E. et al. Mode of reproduction of colchicine-induced Paspalum plicatulum tetraploids. Crop Science, v.49, p.1270-1276, 2009. Available from: <http:// www.crops.org/publications/cs/articles/49/4/1270?highlight $=\&$ search-result $=1>$. Accessed: Oct. 08, 2016. doi: 10.2135/ cropsci2008.05.0270.

SINGH, D. The relative importance of characters affecting genetic divergence. Indian Journal of Genetics and Plant Breeding, v.41, p.237-245, 1981. Available from: <http://www. indianjournals.com/ijor.aspx?target=ijor:ijgpb\&volume $=41 \&$ issue $=2 \&$ article $=010>$. Accessed: Oct. 28, 2016

VIEIRA, E.A. et al. Comparison among pedigree, morphological and molecular distance measures in oats (Avena sativa) in experiments with and without fungicide. Bragantia, v.64, p.51-60, 2005. Available from: <http://www.scielo.br/pdf/brag/ v64n1/23852.pdf $>$. Accessed: Feb. 2017. doi: 10.1590/S00687052005000100006 . 